\title{
Production of D-fructose from starch by amylase and glucose isomerase
}

\author{
Sang Jin Kim, Ji In Choi, Min Su Choi, Chang-Su Park* \\ Department of Food Science and Technology, Daegu Catholic University, Gyeongsan 38430, Korea
}

\section{Amylase와 glucose isomerase를 이용한 starch로부터 D-fructose의 생산}

\author{
김상진 · 최지인 · 최민수 · 박창수* \\ 대구가톨릭대학교 식품공학과
}

\begin{abstract}
Two commercial enzymes, amylase and glucose isomerase, were applied in sequential and simultaneous enzyme reactions to produce D-fructose from starch. $80 \mathrm{U} / \mathrm{g}$ Fungamyl $800 \mathrm{~L}, 35 \mathrm{U} / \mathrm{mL}$ glucose isomerase, and $20 \%$ of starch were the most effective concentrations for this reaction. In the sequential enzyme reaction, Fungamyl 800L maximally produced $56 \mathrm{~g} / \mathrm{L}$ D-glucose from starch at $\mathrm{pH} 5.0$ and $55^{\circ} \mathrm{C}$ for $2 \mathrm{~h}$. Consequently, glucose isomerase was reacted with D-glucose produced from starch by Fungamyl $800 \mathrm{~L}$ at $\mathrm{pH} 6.0$ and $55^{\circ} \mathrm{C}$ for $2 \mathrm{~h}$. This resulted in the production of $18.5 \mathrm{~g} / \mathrm{L} \mathrm{D}$-fructose, however, the production of D-fructose did not increase any more after a 2 h enzyme reaction. In the simultaneous enzyme reaction, Fungamyl 800L and glucose isomerase were simultaneously reacted with starch at $\mathrm{pH} 5.0$ and $55^{\circ} \mathrm{C}$. In the simultaneous reaction, D-fructose production continued to increase as the reaction time increased and finally $39 \mathrm{~g} / \mathrm{L}$ D-fructose was produced from starch after $18 \mathrm{~h}$. Based on these results, the simultaneous enzyme reaction was found to be more efficient than the sequential enzyme reaction with respect to the production of $D$-fructose from starch using amylase and glucose isomerase.
\end{abstract}

Key words : amylase, enzyme reaction, D-fructose, glucose isomerase, starch

서 론

과당(D-fructose 또는 levulose)은 포도당(D-glucose)의 이 성질체로서 당류 중에서 가장 높은 감도를 보유하고 있는 keto-hexose이며, 높은 수용성과 비결정성의 특성으로부터 현대 식품산업에서 설탕대체 감미료로서 다양한 식품 및 음 료에 그 활용성이 지속적으로 증가하고 있는 천연 당질 소재 이다(Hanover, 1993; Parker 등, 2010). 최근 식품산업에서는 설탕 대체 감미료의 중요성이 나날이 증가하고 있어 산업적 요구성에 맞춰 다양한 대체 감미료가 개발되고 있는데, 그 중 에서도 특히 D-fructose가 주성분인 High-Fructose Corn Syrup
(HFCS)은 현대 식품산업에서 높은 산업적 활용성을 보유하 고 있는 설탕대체 감미료로서 많은 주목을 받고 있으며, 최근 에는 자연계에 미량으로 존재하지만 저칼로리라는 높은 생리 활성을 보유한 희소당 중 하나인 D-allulose가 설탕 대체 감 미료로서 높은 잠재적 활용가치를 내포하고 있는 소재로서 많은 산업적 관심을 받고 있다. 희소당 D-allulose의 생산은 $\mathrm{D}$-fructose의 에피머반응에 의해 생산이 이루어지고 있으므로 현대 식품산업에서 높은 주목을 받고 있는 High-Fructose Corn Syrup(HFCS)과 D-allulose의 생산에 있어서 D-fructose 는 핵심적인 원료물질로써 주목을 받고 있다(Amaral-Fonseca 등, 2021; Takeshita 등, 2000; Zhu 등, 2019). 현대식품산업

*Corresponding author. E-mail : parkcs@cu.ac.kr, Phone :+82-53-850-3216, Fax : +82-53-359-6858

Received 08 July 2021; Revised 26 July 2021; Accepted 30 July 2021.

Copyright (c) The Korean Society of Food Preservation.

This is an Open Access article distributed under the terms of the Creative Commons Attribution Non-Commercial License (http://creativecommons.org/licenses/by-nc/4.0) which permits unrestricted non-commercial use, distribution, and reproduction in any medium, provided the original work is properly cited. 
에 있어서 설탕을 대체하는 감미료의 개발의 중요성과 설탕 대체 감미료에 대한 산업적 수요가 지속적으로 증가하고 있 으므로 D-fructose의 생산 기술의 확립은 현대 식품산업의 설 탕대체 감미료 생산에 있어서 매우 중요한 요소라고 할 수 있다.

일반적으로 D-fructose는 과일, 벌꿀, 채소 및 사탕수수와 같은 농산물이 주요 공급원이지만, D-glucose의 이성화 반응 을 통하여 D-glucose로부터 D-fructose를 생산할 수도 있다. 그리고, 현대 식품산업에서 D-glucose를 D-fructose로 전환 하는 연구 기술은 당질의 감도를 향상시켜 설탕 사용량을 감 소시키기 위한 산업적 기술로도 폭넓게 활용되고 있으며, 또 한 산업적 활용성이 높은 D-fructose의 생산 기술로서 활용될 수 있는 산업적 요구성이 높은 연구 기술이라고 할 수 있다 (Kaneko 등, 2000). 이러한 관점에서 D-glucose로부터 Dfructose의 생산을 위해서는 D-glucose의 확보가 선행될 필요 가 있기에 본 연구에서는 D-glucose 확보를 위하여 Dglucose가 구성 단당으로 이루어져 있는 다당체인 전분 (starch)에 주목하였다.

전분은 D-glucose 단위체가 $\alpha-1,4$ 그리고, $\alpha-1,6$ glucosidic bond를 통해 결합되어 있는 순수 다당체로서 amylose(20$30 \%)$ 와 분지형태의 amylopectin(70-80\%)으로 구성되어 있 으며, 특히 농산물에 광범위하게 존재하는 천연 당질 소재이 다(Shofiyah 등, 2020; Luz 등, 2008). 이러한 전분으로부터 구성 성분 단위 물질인 D-glucose를 확보하여 D-fructose로 전환한다면 다당체인 starch로부터 산업적 활용성이 높은 $\mathrm{D}$ fructose를 생산하는 산업적 요구성이 높은 연구 기술이 확립 될 수 있을 것으로 기대하였다. 현대 식품산업에서는 다양한 농산물을 적용한 식품개발이 활발하게 진행되고 있으며, 이 러한 산업적 생산의 결과, 전분이 포함된 농산 부산물의 발생 도 지속적으로 증가하고 있다. 그리고, 이러한 전분질의 농산 부산물의 증가는 농산자원의 비효율적인 소비와 함께 농산 부산물의 처리를 위하여 다양한 환경문제도 발생시키고 있다 (Takeshita 등, 2000). 따라서, 친환경적 생물자원인 효소자원 을 활용하여 starch로부터 D-fructose를 생산할 수 있는 연구 기술은 농산 부산물의 전분으로부터 산업적 활용성이 높은 D-fructose를 생산하는 생물학적 기술으로서 농산 부산물을 친환경적으로 재활용함으로써 다양한 환경문제를 감소시킬 수 있으며, 나아가서 농산 부산물의 새로운 부가가치의 창출 에도 기여할 수 있는 연구기술로써 기대되어진다(Kohli 등, 2020; Luz 등, 2008).

전분으로부터 구성 단당인 D-glucose로의 분해를 위해서 는 산, 알칼리를 적용한 화학적 분해 방법과 전분 분해효소인 $\alpha$-amylase(EC 3.2.1.1), $\beta$-amylase(EC 3.2.1.2), 그리고 $\alpha$ glucosidase(EC 3.2.1.20)를 적용한 효소적 분해 방법이 있는
데, 현재 식품산업에서는 보다 친환경적이며 안전한 작업환 경을 제공할 수 있는 효소적 방법이 일반적으로 적용되고 있 다(Priest, 1977; Van der Maarel과 Van der Veen, 2002).

그리고, 전분으로부터 생산된 D-glucose는 glucose isomerase (GI, EC 5.3.1.5)의 가역적인 이성화 반응에 의하여 D-fructose 로 전환시킬 수 있으며, 이러한 효소적 공정은 식품산업에서 High-Fructose Corn Syrup(HFCS)의 핵심 구성당이며, 희소 당 D-allulose의 생산 소재인 D-fructose를 D-glucose로부터 확보하는데 핵심적인 효소적용 기술로서 알려져 있다(Bhosale 등, 1996). 현재 보고되어져 있는 미생물 유래 glucose isomerase 중 본 연구에서는 상업용으로 시판되고 있는 Streptomyces murinus 유래 glucose isomerase를 사용하였다(Karaoglu 등, 2013; Lama 등, 2001; Lee과 Zeikus, 1991). 이와 같이 다당체 인 starch에 전분가수분해효소인 amylase를 적용하여 D-glucose 를 생산하고, glucose isomerase를 starch로부터 생산된 Dglucose에 적용한다면 다당체인 starch로부터 기능성 단당인 D-fructose를 효소적 방법으로 생산할 수 있을 것으로 기대되 며, 이처럼 각각 상이한 효소 활성을 보유한 효소들을 적용하 여 목적 산물을 생산하는 연구기술은 향후 복합적인 효소 반 응을 적용하여 다양한 농산 부산물로부터 기능성 소재를 생 산할 수 있는 새로운 효소의 적용 기술로서도 활용될 수 있을 것으로 기대된다. 나아가서 농산 부산물의 친환경적 재활용 및 부가가치 창출 기술로서도 접목될 수 있을 것으로 기대된 다(Lee 등, 1990; Mukesh 등, 2012; Xu 등, 2021).

따라서, 본 연구에서는 효소 활성이 상이한 두 종류의 상 업용 효소인 전분 가수분해 효소(amylase)와 글루코오스 이 성화 효소(glucose isomerase)를 적용하여 starch로부터 Dfructose를 생산하기 위한 효소 적용 기술 확립을 위하여 효 소 반응에 요구되는 조건(기질농도, 효소농도, 반응 $\mathrm{pH}$, 반응 시간)의 규명과 함께 starch로부터 D-fructose 생산에 효율적 인 효소 반응 방법(순차적 효소 반응 및 동시 효소 반응)에 대한 특성을 규명하였다.

\section{재료 및 방법}

\section{실험재료}

본 연구에 사용된 수용성 전분(starch)는 (주대정시약 (Seoul, Korea)에서 구입하였으며, amylase(BAN480L, Fungamyl 800L, Dextrozyme)는 Novozyme Nordisk (Bagsvaerd, Denmark), 그 리고 Streptomyces murinus 유래 glucose isomerase는 Sigma-Aldrich Co.(St. Louis, Mo, USA)에서 구매하였다. 그 외에 기타 실험에 사용한 시약들은 모두 (주덕산약품공업 (Ansan, Korea), Sigma-Aldrich Co. (St. Louis, Mo, USA)에 서 구매하였다. 


\section{상업용 amylase에 의한 starch 분해}

Starch로부터 D-glucose 생산을 위하여 상업용 amylase인 BAN 480L, Fungamyl 800L, Dextrozyme 3종이 사용되었다. 본 연구에서 사용한 amylase의 starch에 대한 효소활성 측정 을 위하여 효소는 모두 $4 \mathrm{U} / \mathrm{mL}$ 로 동일하게 희석하였다. 희 석한 효소 $150 \mu \mathrm{L}$ 를 $1 \% \operatorname{starch}(50 \mathrm{mM}$ citric acid buffer, $\mathrm{pH}$ 5.0) 기질 $150 \mu \mathrm{L}$ 와 $37^{\circ} \mathrm{C}$ 에서 10 분간 반응한 후 효소 반응에 의해 생성된 환원당을 Miller에 의해 소개된 3,5dinitrosalicylic acid(DNS)시약(Sigma, St. Louis, MO, USA) 을 이용한 DNS법에 의해 검토하였다(Miller, 1959). 본 연구 에서의 amylase 효소활성 1 unit(U)은 Novozyme의 효소활 성측정 표준방법으로 제시되어 있는 시간당 $5.26 \mathrm{~g}$ 의 전분을 분해하는 효소량으로 정의하였다.

\section{Starch 분해에 미치는 $\mathrm{pH}$ 및 온도의 영향 측정}

Fungamyl $800 \mathrm{~L}$ 이 starch 분해에 미치는 $\mathrm{pH}$ 의 영향을 검 토하기 위하여 $\mathrm{pH}$ 3.0-7.0 범위에서 효소활성을 검토하였다. Buffer $50 \mathrm{mM}$ citric acid buffer $(\mathrm{pH}$ 3.0-6.0)와 $50 \mathrm{mM}$ phosphate buffer( $\mathrm{pH}$ 6.0-7.0)를 이용하여 각 $\mathrm{pH}$ 의 $1 \%$ starch 기질을 제조하였으며, 기질 $150 \mathrm{~mL}$ 에 $4 \mathrm{U} / \mathrm{mL}$ 효소 $150 \mathrm{~mL}$ 를 첨가하여 $37^{\circ} \mathrm{C}$ 에서 10 분간 반응한 후 효소 반응에 의해 생성된 환원당을 $\mathrm{DNS}$ 법으로 검토하였다. 그리고, 온도가 효 소 활성에 미치는 영향을 검토하기 위하여 효소 반응은 $30^{\circ} \mathrm{C}$ 에서 $70^{\circ} \mathrm{C}$ 온도 범위에서 진행되었으며, $1 \% \operatorname{starch}$ 기질 $(\mathrm{pH}$ 5.0) $150 \mu \mathrm{L}$ 에 $4 \mathrm{U} / \mathrm{mL}$ 효소 $150 \mu \mathrm{L}$ 를 첨가하여 각 온도에서 10 분간 반응한 후 효소 반응에 의해 생성된 환원당을 DNS법 으로 검토하였다.

\section{Starch로부터 D-glucose 생산에 대한 최적 기질농도 및 효소농도 측정}

Fungamyl 800L에 의한 starch로부터 D-glucose 최대 생산 을 위한 starch 농도 및 Fungamyl 800L 농도 규명을 위하여, $1,5,10,15,20 \%$ 의 starch 농도에 대하여 $400 \mathrm{U} / \mathrm{g}$ 의 Fungamyl $800 \mathrm{~L}$ 을 이용하여 $\mathrm{pH} 5.0,50^{\circ} \mathrm{C}$ 조건에서 4 시간 동안 반응을 진행한 후, 생산된 D-glucose를 분석하였다. Starch로부터 D-glucose 생산에 최적의 효소농도를 규명하기 위하여 10 , $20,40,80,160 \mathrm{U} / \mathrm{g}$ 의 Fungamyl $800 \mathrm{~L}$ 을 $20 \%$ starch와 $\mathrm{pH}$ $5.0,50^{\circ} \mathrm{C}$ 조건에서 10 시간 동안 반응하여 반응시간에 따른 $\mathrm{D}$-glucose 생산량을 분석하였다. 본 연구에서 D-glucose 생 산량은 BIO-LC system(Dionex ICS-3000, Sunnyvale, CA, Thermo Fisher Scientific, USA)에서 CarboPac PAI column 에 의해 분석하였다.

\section{Buffer 농도가 amylase 활성에 미치는 영향 측정}

Buffer의 농도가 Fungamyl 800L의 starch 분해에 미치는
영향을 검토하기 위하여, $1,5,10,20,30,40$, 그리고, 50 $\mathrm{mM}$ citric acid buffer(pH 5.0)를 제조한 후 20\% starch와 혼 합하여 기질을 제조하였다. $80 \mathrm{U} / \mathrm{g}$ 의 Fungamyl $800 \mathrm{~L}$ 을 각각 의 기질에 첨가하여 $50^{\circ} \mathrm{C}$ 에서 4 시간 동안 반응을 진행한 후 Fungamyl 800L에 의해 starch로부터 분해 생산된 D-glucose 를 분석하였다.

\section{D-Glucose로부터 D-fructose 생산을 위한 glucose isomerase 최적농도 측정}

본 연구에서 D-glucose로부터 D-fructose 생산을 위하여 이용한 glucose isomerase는 Sigma(St. Louis, MO, USA)에 서 S. murinus 유래 glucose isomerase를 구입하여 실험에 사 용하였다. S. murinus 유래 glucose isomerase를 3.5-35 U/mL 범위의 다양한 농도를 $20 \%$ starch와 Fungamyl $800 \mathrm{~L}(80$ $\mathrm{U} / \mathrm{g}$ )의 4시간 반응액에 첨가하여 glucose isomerase 최적 반 응 조건인 $\mathrm{pH} 7.5$ (100 mM phosphate buffer), $55^{\circ} \mathrm{C}$ 에서 20분 간 반응하여 D-fructose를 최대로 전환하는 glucose isomerase 의 효소 농도를 규명하였다. 각각의 효소농도 반응에 대한 반 응종료는 최종농도 $200 \mathrm{mM} \mathrm{HCl}$ 을 첨가하여 효소반응을 종 료하였으며, 반응 결과 생산된 D-fructose는 Bio-LC 시스템 을 이용하여 분석하였다. 본 연구에서 glucose isomerase의 1 unit(U)은 최적 반응조건에서 D-glucose로부터 1분간에 1 $\mu \mathrm{mol}$ 의 D-fructose를 생산하는 효소량으로 정의하였다.

\section{Glucose isomerase 반응시간에 의한 D-glucose로부터 D-fructose 생산}

S. murinus 유래 glucose isomerase의 반응시간에 대한 D-glucose로부터 D-fructose 생산을 검토하기 위하여 $20 \%$ soluble starch와 $80 \mathrm{U} / \mathrm{g}$ Fungamyl $800 \mathrm{~L}$ 의 4시간 반응액에 S. murinus 유래 glucose isomerase $(35 \mathrm{U} / \mathrm{mL})$ 를 첨가하여 $\mathrm{pH}$ 7.5(100 mM phosphate buffer), $55^{\circ} \mathrm{C}$ 조건에서 효소반응 을 10-180분간 진행시키면서 각각의 반응시간에 대한 반응 시료 $10 \mu \mathrm{L}$ 를 채취하여 $200 \mathrm{mM} \mathrm{HCl}$ 을 이용하여 반응종료 후 반응시간에 대한 D-fructose 생산을 Bio-LC 분석에 의해 진행하였다.

\section{효소 동시반응에서 $\mathrm{pH}$ 의 영향 측정}

Starch로부터 D-fructose를 Fungamyl 800L과 glucose isomerase 두 효소의 동시효소반응에 의해 생산하기 위하여 최적 $\mathrm{pH}$ 가 상이한 두 효소의 동시반응에 $\mathrm{pH}$ 가 미치는 영향 을 검토하였다. Fungamyl $800 \mathrm{~L} 80 \mathrm{U} / \mathrm{g}$ 의 효소와 glucose isomerase $35 \mathrm{U} / \mathrm{mL}$ 를 $\mathrm{pH}$ 3.0-9.0 범위의 각각의 buffer로 제 조한 $20 \%$ starch 기질과 $55^{\circ} \mathrm{C}$ 에서 20 분간 반응하였다. 본 반 응에서 $\mathrm{pH}$ 3.0-6.0은 $50 \mathrm{mM}$ citric acid buffer, $\mathrm{pH}$ 6.0-8.0은 
$50 \mathrm{mM}$ phosphate buffer, 그리고 $\mathrm{pH}$ 8.0-9.0은 $50 \mathrm{mM}$ Tris buffer를 이용하여 조성하였다. 두 효소의 동시반응에 의해 starch로부터 D-glucose와 D-fructose 생산에 미치는 $\mathrm{pH}$ 의 영향을 검토하기 위하여 반응액을 일정 시간 간격으로 $10 \mu \mathrm{L}$ 씩 채취한 후 $200 \mathrm{mM} \mathrm{HCl}$ 를 첨가하여 반응을 종료시킨 후 Bio-LC 시스템에 의해 생산된 D-glucose와 D-fructose를 분 석하였다.

\section{효소 동시반응에 의한 D-fructose 생산}

$20 \% \operatorname{starch}(50 \mathrm{mM}$ phosphate buffer, $\mathrm{pH} 6.0)$ 을 기질로 이 용하여 $80 \mathrm{U} / \mathrm{mL}$ Fungamyl $800 \mathrm{~L}$ 그리고, $35 \mathrm{U} / \mathrm{mL}$ glucose isomerase를 동시에 첨가하여 $55^{\circ} \mathrm{C}$ 에서 효소 동시반응에 의 한 starch로부터 D-fructose 생산을 검토하였다. 두 효소의 동 시반응액은 일정한 반응시간 간격으로 $10 \mu \mathrm{L}$ 씩 채취된 후 최 종농도 $200 \mathrm{mM} \mathrm{HCl}$ 에 의해 반응 종료 후 Bio-LC 시스템에 의하여 생산된 D-fructose를 분석하였다.

\section{반응산물(단당) 분석}

효소반응에 의해 생산된 반응 산물은 반응 종료 후 원심분 리 $(10,000 \times g, 10 \mathrm{~min})$ 를 통해 상층액을 회수하고, 상층액을 1,000 배 희석하여 $0.2 \mu \mathrm{m}$ filter(ADVANTEC, Japan)에 통과 시킨 후 BIO-LC system(Dionex ICS-3000, Sunnyvale, CA, Thermo Fisher Scientific, USA)에서 CarboPac PAI column 에 의해 분석되었다. 분석 조건은 distilled water와 $200 \mathrm{mM}$ $\mathrm{NaOH}$ 를 75:25 비율로 혼합한 용출용매를 $0.5 \mathrm{~mL} / \mathrm{min}$ 유속 으로 실온에서 분석하였다.

\section{결과 및 고찰}

\section{상업용 amylase에 의한 starch 분해}

본 연구는 starch로부터 D-fructose를 생산하기 위하여 amylase의 가수분해 반응에 의하여 starch로부터 구성 단당인 D-glucose를 생산하고, D-glucose를 기질로 활용하여 이성화
효소인 glucose isomerase와 반응하여 최종적으로 D-fructose 를 생산하는 과정으로 효소반응이 구성되어져 있다(Fig. 1). 그 러므로, starch로부터 본 연구의 최종 목적 산물인 D-fructose를 생산하기 위해서는 starch로부터 D-fructose 생산에 적용되는 D-glucose를 효율적으로 생산하는 amylase 선정이 중요한 연 구라고 할 수 있다. Starch의 가수분해 방법으로는 산 가수분 해(Lee 등, 1997), 초임계 처리 가수분해(Miyafuji 등, 2005; Nakata 등, 2006) 등에 의한 가수분해가 보고되어져 있지만, 본 연구에서는 현대식품산업에서 starch 가수분해에 높게 적 용되고 있는 효소반응을 통하여 starch로부터 D-glucose를 생산하기 위하여 상용화되고 있는 3종의 amylase(Fungamyl 800L, BAN 480L, Dextrozyme)을 이용하여 starch에 대한 높은 가수분해 활성을 보유한 효소에 대한 검토를 진행하였 다. 그 결과, Fungamyl $800 \mathrm{~L}$ 이 starch에 대하여 가장 높은 가수분해 활성을 나타내었으며, BAN 480L과 Dextrozyme은 Fungamyl $800 \mathrm{~L}$ 의 starch에 대한 가수분해 활성과 비교하여 각각 $33 \%, 9 \%$ 의 효소 활성을 나타내었다(Fig. 2). Starch로 부터 D-fructose를 생산하는 반응은 starch로부터 D-glucose 를 생산하고, glucose isomerase에 의해 starch로부터 생산된 $\mathrm{D}$-glucose를 D-fructose로 전환하는 2단계 효소 반응으로 진 행되기에 starch로부터 D-glucose를 최대한 많은 양을 생산 할 수 있는 starch 가수분해 활성이 높은 amylase의 선정은 무엇보다도 중요한 효소선정에 대한 검토라고 할 수 있다. 따 라서, starch에 대한 가장 높은 가수분해활성을 보유한 amylase 는 starch로부터 구성 단당인 D-glucose를 최대로 생산할 수 있 는 효소 활성을 보유한 효소라고 판단되어, 본 연구에서는 starch 로부터 D-glucose를 생산하기 위한 amylase로서 Fungamyl $800 \mathrm{~L}$ 을 선정하였다.

\section{Starch로부터 D-glucose 생산에 대한 최적 기질농도 및 효소농도}

본 연구에서는 Fungamyl 800L에 의해 starch로부터 Dglucose를 생산을 위한 최적의 starch 농도에 대한 검토를 진

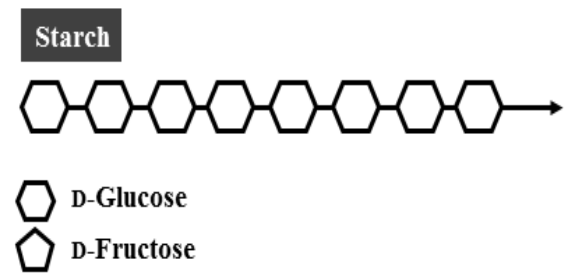

Hydrolysis

Amylase

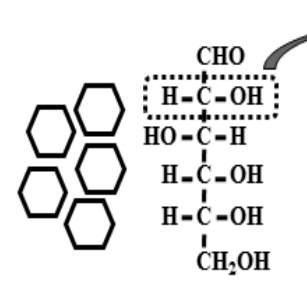

D-Glucose

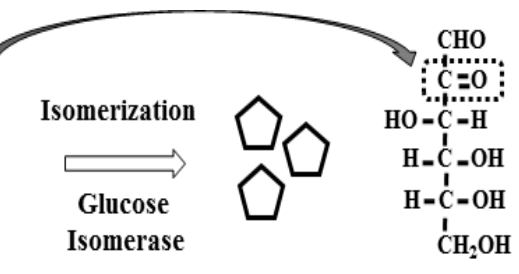

D-Fructose

Fig. 1. Procedure of enzyme reactions to produce D-fructose from starch.

Starch is decomposed into D-glucose by hydrolysis reaction of amylase and then D-glucose is converted to D-fructose by isomerization of glucose isomerase. 


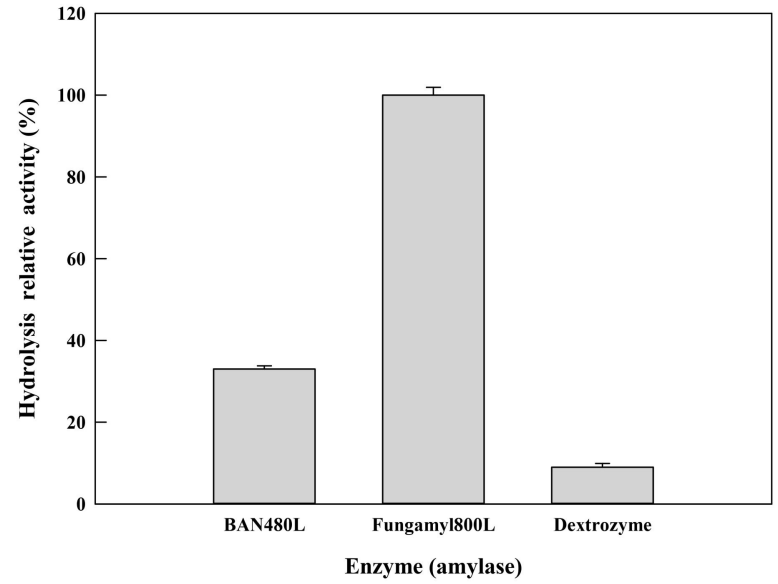

Fig. 2. Hydrolysis activity of amylases (BAN480L, Fungamyl 800L, Dextrozyme) on starch.

Each reaction was performed in $50 \mathrm{mM}$ citric acid buffer ( $\mathrm{pH} 5.0$ ) containing $1 \%$ starch and 4 unit $/ \mathrm{mL}$ enzyme and then the produced reducing sugars by enzyme activity was measured by DNS method. Data represent the means of three experiments with standard deviation $(\mathrm{p}<0.05)$.

행하였다. Fungamyl 800L에 의해 starch로부터 D-glucose를 생산하는 과정은 glucose isomerase에 의해 D-fructose를 생 산하기 위한 기질인 D-glucose를 생산하는 효소반응으로서 D-glucose의 최대생산에 가장 효율적인 starch 기질의 농도 규명은 최종적으로 D-fructose의 생산성을 향상시키는 매우 중요한 효소 반응이라고 할 수 있다. 본 연구에서는 최적의 starch 기질 농도를 규명하기 위하여 $1-20 \%$ 농도 범위의 starch를 기질로 이용하여 Fungamyl 800L의 가수분해 활성에 의해 생산되는 D-glucose를 분석하였다. 각각의 기질 농도 starch와 Fungamyl $800 \mathrm{~L}$ 을 $55^{\circ} \mathrm{C}, \mathrm{pH} 5.0$ 조건에서 4시간 동 안 반응하였을 때, $1 \%, 5 \%, 10 \%, 15 \%$, 그리고 $20 \%$ 의 starch 농도에서 D-glucose는 각각 $4.8,20,36,48$, 그리고 $56 \mathrm{~g} / \mathrm{L}$ 가 생산되었으며, starch의 농도가 증가하면 할수록 생산되는 D-glucose의 양은 지속적으로 증가하는 결과를 보였다(Fig. 3). 본 연구에서는 $20 \%$ starch로부터 가장 높은 D-glucose 생 산이 확인 되었으며, $1 \%$ starch 기질 농도와 비교하였을 때 $20 \%$ starch 농도에서는 약 11.7 배 높은 D-glucose 생산을 보 였다. 이러한 결과로부터 starch 농도가 높을수록 Fungamyl $800 \mathrm{~L}$ 의 가수분해 활성에 의해 D-glucose 생산량이 증가할 것이라는 것이 예상되었지만, 본 연구에서 기질로 활용한 starch 기질은 $20 \%$ 를 초과하는 농도에서는 완전한 용해가 이 루어지지 않아 $20 \%$ 보다 높은 starch 기질을 효소반응에 적용 하지는 못하였다. 하지만, 본 연구의 결과로부터 $20 \%$ 이상의 starch 기질 제조가 가능한 기질제조방법의 검토 또는 고농도 용해가 가능한 starch 기질의 검토가 이루어진다면 Fungamyl $800 \mathrm{~L}$ 의 가수분해 활성에 의해 보다 더 높은 D-glucose를

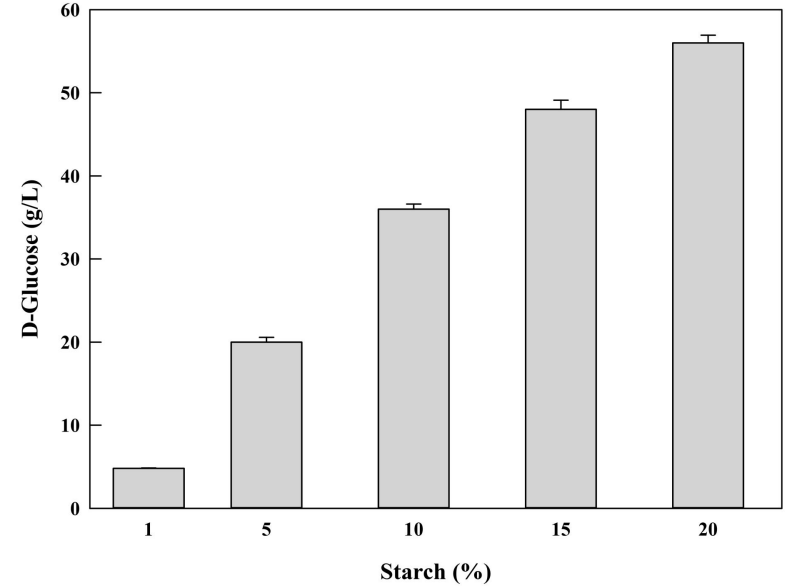

Fig. 3. Effect of starch concentration on the production of D-glucose from starch by Fungamyl 800L.

Various concentrations of starch were prepared as substrates for Fungamyl $800 \mathrm{~L}$ and then each reaction was carried out at $\mathrm{pH} 5.0$ and $55^{\circ} \mathrm{C}$ for 4 hours. After the reaction, D-glucose produced from starch in each reaction was analyzed in the Bio-LC system using a CarboPac PAI column. Data represent the means of three experiments with standard deviation $(\mathrm{p}<0.05)$.

starch로부터 생산 가능할 것으로 기대되며, 이러한 결과는 최종적으로 starch로부터 D-fructose 생산의 향상에도 기여할 수 있을 것으로 기대된다.

본 연구에서 규명한 $20 \%$ starch로부터 D-glucose를 생산 하는데 있어서 최적의 효소농도를 규명하기 위하여 $20 \%$ starch와 10-160 U/g 농도 범위의 Fungamyl 800L을 각각 반 응하여 효소반응에 의해 생산된 D-glucose를 분석하였다. 그 결과, 효소 농도가 증가하면 할수록 starch로부터 생산되는 D-glucose량은 향상되었으며, $80 \mathrm{U} / \mathrm{g}$ 과 $160 \mathrm{U} / \mathrm{g}$ 의 효소 농 도에서는 반응 4시간 후에 D-glucose 생산량이 $56 \mathrm{~g} / \mathrm{L}$ 의 최 대 생산량에 도달하는 것으로 확인되었다(Fig. 4). 그리고, $10,20,40 \mathrm{U} / \mathrm{g}$ 의 효소 농도에서는 반응시간 4 시간 이후에 D-glucose 생산량이 각각 $13,24,40 \mathrm{~g} / \mathrm{L}$ 로 $80,160 \mathrm{U} / \mathrm{g}$ 의 효소량에서 확인되었던 D-glucose의 최대 생산량에 도달하 지 못하는 것으로 검토되었다(Fig. 4). 본 반응에 있어서 효소 반응을 10 시간까지 증가시켜 Fungamyl $800 \mathrm{~L}$ 가수분해반응 에 의해 생산되는 D-glucose를 분석하였는데, 4시간 효소 반 응 후 생산된 D-glucose와 큰 변화 없이 일정하게 D-glucose 생산량이 유지되는 특성을 모든 효소 농도 범위에서 보였으므 로(data not shown), 이러한 결과로부터 $80 \mathrm{U} / \mathrm{g}$ 의 Fungamyl $800 \mathrm{~L}$ 를 이용하여 $20 \% \mathrm{starch}$ 와 4시간의 효소반응이 starch로 부터 D-glucose를 생산하는 최적의 반응 조건임을 확인하였다.

\section{Buffer 농도가 amylase 활성에 미치는 영향}

본 연구에서는 효소활성이 상이한 두 종류의 효소를 적용 


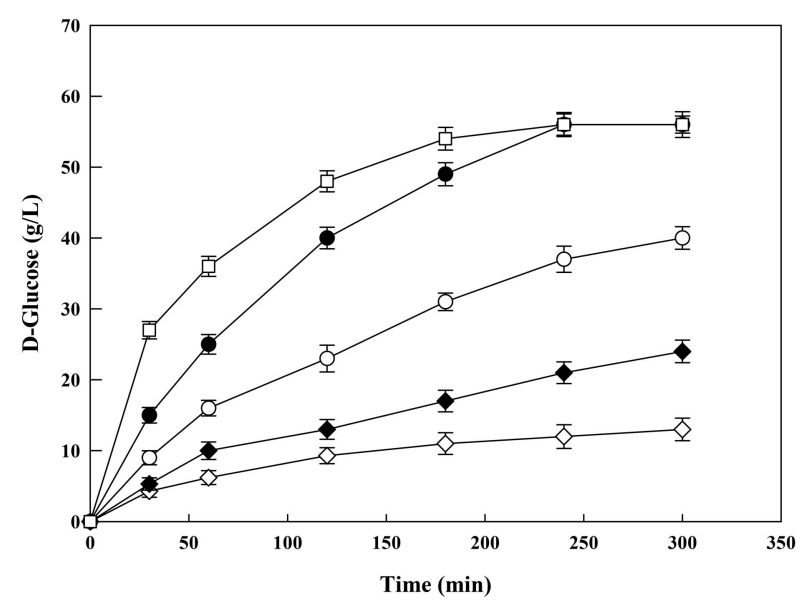

Fig. 4. Effect of Fungamyl 800L concentration on the production of D-glucose from $20 \%$ starch.

The Fungamyl 800L activity was adjusted 10-160 U/g (10 (open diamond), 20 (closed diamond), 40 (open circle), 80 (closed circle), and $160 \mathrm{U} / \mathrm{g}$ (open square)) and then each enzyme was reacted with $20 \%$ starch at $\mathrm{pH} 5.0$ and $55^{\circ} \mathrm{C}$ for 10 hour. After the reaction, D-glucose produced from starch in each reaction was analyzed in the Bio-LC system using a CarboPac PAI column. $10 \mathrm{U} / \mathrm{g}$ (Data represent the means of three experiments with standard deviation $(\mathrm{p}<0.05)$.

하여 starch로부터 D-fructose를 생산하기 위하여 두 효소를 순차적으로 반응하는 방법과 동시에 효소 반응을 진행하는 2가지 방법으로 효소 반응을 진행하였다. 순차적 효소 반응 에 의한 starch로부터 D-fructose 생산방법에서는 첫 번째 효 소 반응으로서 전분가수분해효소인 Fungamyl 800L를 starch 와 반응시킨 후 Fungamyl $800 \mathrm{~L}$ 의 가수분해 활성에 의해 starch로부터 D-glucose를 생산하고, 생산된 D-glucose는 glucose isomerase의 이성화반응에 의해 D-fructose를 생산하 는 효소의 순차적인 반응으로 구성되어져 있다. 본 연구에서 starch로부터 D-fructose를 생산하는 공정에 적용한 amylase 인 Fungamyl 800L과 Streptomyces murinus 유래 glucose isomerase의 최적온도는 $55^{\circ} \mathrm{C}$ 로 동일하였지만, 최적 $\mathrm{pH}$ 가 각 각 5.0과 7.5로서 매우 상이한 특성을 보이고 있었다. 본 반응 은 starch로부터 D-glucose를 생산하기 위하여 Fungamyl $800 \mathrm{~L}$ 을 반응시킨 후 순차적으로 glucose isomerase를 첨가하 여 D-fructose를 생산하는 연속반응으로 진행되기에 첫 번째 효소반응인 Fungamyl 800L의 반응에서 저농도의 buffer에서 반응이 진행된다면 뒤이어 첨가되는 glucose isomerase에 대 한 최적 $\mathrm{pH}$ 조건을 보다 더 용이하게 설정할 수 있어서 $\mathrm{pH}$ 특성이 상이한 가수분해효소와 이성화 효소의 순차적인 연속 반응을 통해 starch로부터 D-fructose를 보다 더 원활하게 생 산 할 수 있는 효소 반응 조건을 확립할 수 있을 것으로 기대 하였다. 그러나 buffer의 농도는 효소활성에 영향을 미치는 중요한 반응조건으로 보고되어 있기에(Reshmi 등, 2006), 본
연구에서는 Fungamyl 800L에 의한 starch로부터 D-glucose 생산에 있어서 buffer 농도가 미치는 영향을 검토하였다. Buffer로서 1-50 mM 농도의 citric acid buffer(pH 5.0)를 이 용하여 $20 \%$ starch 기질을 제조하여 Fungamyl $800 \mathrm{~L}$ 과 $55^{\circ} \mathrm{C}$ 에 서 $4 \mathrm{~h}$ 반응시킨 후 생산된 D-glucose를 검토하였다. Starch 로부터 D-glucose 생산에 있어서 Fungamyl 800L은 효소 반 응 4시간 후에 buffer 농도의 영향을 받지 않고 모든 농도의 buffer로 제조된 starch 기질로부터 D-glucose 생산량의 변화 를 보이지 않고 최대 생산량에 도달하는 것으로 확인되었다 (Fig. 5). 이러한 결과로부터 Fungamyl 800L은 starch로부터 D-glucose 생산에 있어서 1-50 mM buffer 농도의 범위에서 는 buffer 농도의 영향을 받지 않는다는 것을 알 수 있었다. Fungamyl 800L과 glucose isomerase의 순차적인 효소반응에 의해 starch로부터 D-fructose를 생산하는 반응에 있어서 첫 번째 반응으로 Fungamyl 800L에 의해 진행되는 starch 가수 분해 반응은 $\mathrm{pH} 5.0$ 에서 진행되는 반응으로서 뒤이어 진행되 는 glucose isomerase 효소반응에 요구되는 $\mathrm{pH}$ 7.5와는 상이 한 $\mathrm{pH}$ 조건이라고 할 수 있다. 순차적 효소 반응에 있어서 뒤이어 반응하는 glucose isomerase의 $\mathrm{pH} 7.5$ 환경을 보다 더 원활하게 조성하는 것이 효율적으로 효소 반응을 진행시킬 수 있을 것으로 판단되어, Fungamyl 800L에 의해 진행되는 starch로부터 D-glucose를 가수분해 반응의 $\mathrm{pH}$ 환경을 최대 한 낮은 농도의 buffer에 의해 조성된다면 뒤이어 순차적으로 진행되는 glucose isomerase가 요구하는 $\mathrm{pH} 7.5$ 환경을 보다 더 효과적으로 조성할 수 있을 것으로 기대되었다. 이러한 연 구 결과로부터, 본 연구에서는 최저 농도인 $1 \mathrm{mM}$ 의 citric acid buffer(pH 5.0)를 이용하여 Fungamyl 800L에 의한 starch로

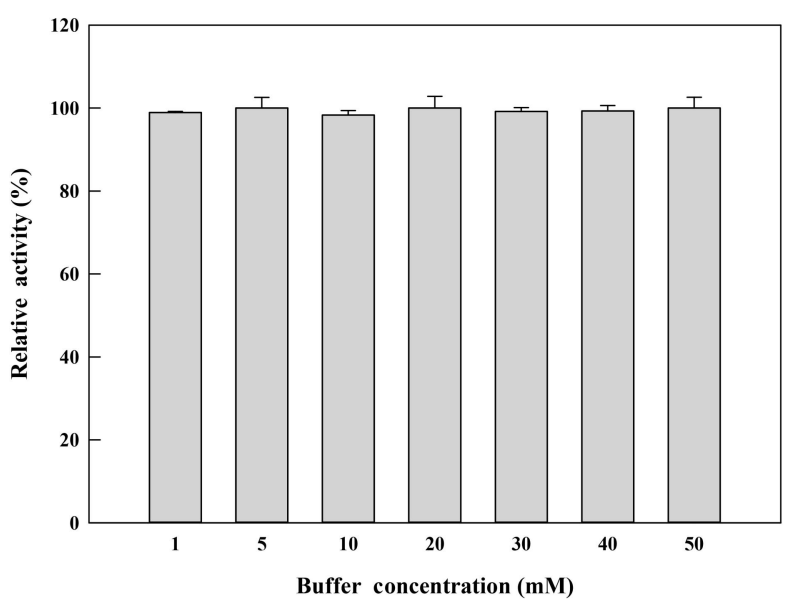

Fig. 5. Effect of buffer concentration on Fungamyl 800L activity. The Fungamyl $800 \mathrm{~L}$ was mixed with $20 \%$ starch prepared in various concentrations of citric acid buffer ( $\mathrm{pH} 5.0)$ at $55^{\circ} \mathrm{C}$ for $4 \mathrm{~h}$. Data represent the means of three experiments with standard deviation $(\mathrm{p}<0.05)$. 
부터 D-glucose 생산 반응을 수행하였다.

\section{D-Glucose로부터 D-fructose 생산을 위한 glucose isomerase 최적 농도}

Glucose isomerase는 D-glucose를 이성화 반응에 의해 Dfructose로 전환하는 효소로서(Tsumura과 Sato, 1965), starch 로부터 생산된 D-glucose로부터 D-fructose를 생산하기 위해 서는 glucose isomerase에 의한 starch로부터 생산된 D-glucose 의 이성화반응이 요구된다. 따라서, 본 연구에서도 이성화반 응을 통하여 D-glucose로부터 D-fructose를 생산하기 위하여 상업용 효소인 Streptomyces murinus 유래 glucose isomerase 를 이용하여 연구를 수행하였다. Fugamyl $800 \mathrm{~L}$ 의 가수분해 활성을 통해 starch로부터 생산된 D-glucose를 D-fructose를 전환하는데 요구되는 최적의 glucose isomerase 농도를 검토하 였다. Fungamyl 800L에 의해 starch로부터 생산된 D-glucose에 2.8-35 U/mL 농도 범위의 S. murinus 유래 glucose isomerase 를 각각 농도별로 첨가하여 $\mathrm{pH} 7.5,55^{\circ} \mathrm{C}$ 조건에서 반응을 진행시킨 후 D-fructose 생성량을 비교 검토하였다. 본 연구 로부터 D-glucose는 glucose isomerase의 농도가 증가함에 따라 D-fructose의 생산량이 지속적으로 증가하는 특성을 보 였다(Fig. 6). 하지만, 본 연구에 사용한 glucose isomerase는 고정화 효소로 제조되어 있는 효소로서 일정한 부피를 보유하 고 있어서 $35 \mathrm{U} / \mathrm{mL}$ 보다 높은 농도의 glucose isomerase 첨가 는 어려움이 있었다. 따라서, 본 연구에서는 glucose isomerase 로서 최대로 적용할 수 있는 $35 \mathrm{U} / \mathrm{mL}$ 의 glucose isomerase를

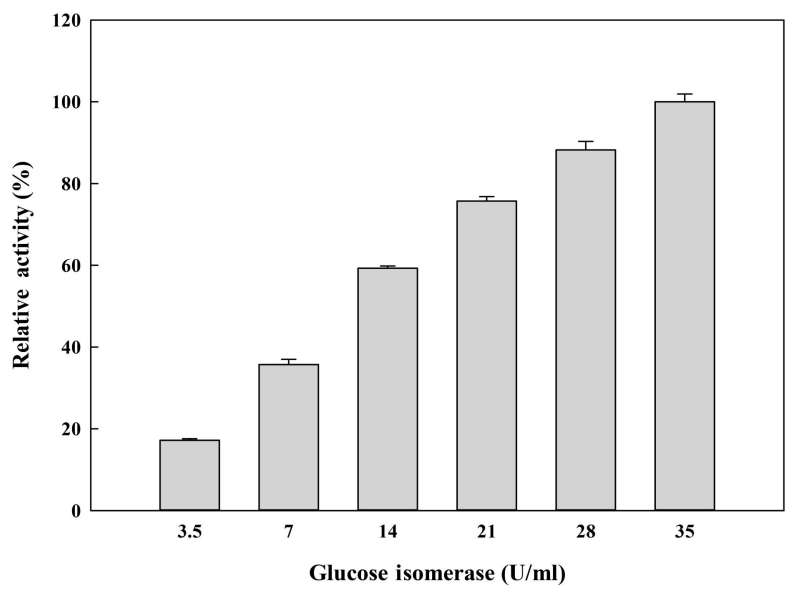

Fig. 6. Effect of glucose isomerase concentration on D-fructose production from D-glucose.

Each glucose isomerase prepared in various units was added into the reaction mixture reacted with starch and Fungamyl $800 \mathrm{~L}$ at $\mathrm{pH} 7.5$ and $55^{\circ} \mathrm{C}$ for $20 \mathrm{~min}$. After the reaction, D-fructose produced in each reaction was analyzed in the Bio-LC system using a CarboPac PAI column. Data represent the means of three experiments with standard deviation $(\mathrm{p}<0.05)$.
이용하여 starch로부터 생산된 D-glucose를 D-fructose로 전 환하는데 사용하였다. 하지만, 본 연구의 결과로부터 glucose isomerase의 첨가 농도를 향상시킬 수 있는 연구방법이 구축 된다면 starch로부터 보다 더 효율적으로 D-fructose를 생산 할 수 있는 시스템이 구축될 수 있다는 것이 시사되었다.

\section{Glucose isomerase 반응시간에 의한 D-glucose로부터 D-fructose 생산}

Starch로부터 생산된 D-glucose로부터 D-fructose를 생산하 기 위한 glucose isomerase의 최적 반응시간을 규명하기 위하 여, starch와 Fungamyl 800L의 반응에 의해 생산된 D-glucose $(56 \mathrm{~g} / \mathrm{L})$ 에 glucose isomerase $(35 \mathrm{U} / \mathrm{mL})$ 를 첨가하여 $\mathrm{pH} 7.5$, $55^{\circ} \mathrm{C}$ 조건에서 반응시간에 따른 D-fructose 생산량을 검토하 였다. 그 결과, glucose isomerase 첨가 후 반응시간이 증가할 수록 D-fructose의 생산량은 지속적으로 증가하다가 반응 2 시간에 도달하였을 때, D-fructose의 최대 생산량 $(18.7 \mathrm{~g} / \mathrm{L})$ 을 나타내었으며, 반응 2 시간 이후에는 반응시간이 증가하 여도 D-fructose 생산량의 증가는 보이지 않았다(Fig. 7). Fungamyl 800L과 glucose isomerase의 순차적 효소반응 (sequential enzyme reaction)에 의해 starch로부터 D-fructose 생산에 있어서, 첫 번째 반응인 $20 \%$ starch와 Fungamyl $800 \mathrm{~L}$ 의 반응에 의해 약 $56 \mathrm{~g} / \mathrm{L}$ 의 D-glucose가 생산되었다. 그리고, 순차적으로 뒤이은 glucose isomerae의 이성화반응 에 의해 starch로부터 생산된 $56 \mathrm{~g} / \mathrm{L}$ 의 D-glucose로부터 18.7 $\mathrm{g} / \mathrm{L}$ 의 D-fructose가 최종적으로 생산되면서 약 $33.3 \%$ 의 전환

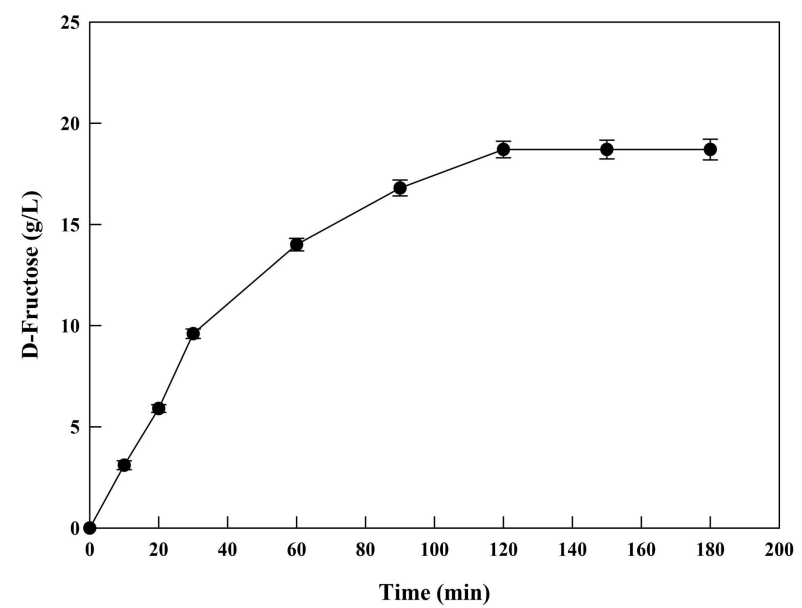

Fig. 7. Effect of enzyme reaction time on D-fructose production.

The glucose isomerase $(35 \mathrm{U} / \mathrm{mL})$ was added in the reaction solution including D-glucose from starch to produce D-fructose. And then the reaction was carried out at $\mathrm{pH} 7.5$ and $55^{\circ} \mathrm{C}$ for $3 \mathrm{~h}$. After the reaction, D-fructose produced in each reaction was analyzed in the Bio-LC system using a CarboPac PAI column. Data represent the means of three experiments with standard deviation $(\mathrm{p}<0.05)$. 
률로 D-glucose로부터 D-fructose가 생산되는 것으로 검토되 었다. 현재까지 보고되어져 전분질을 이용한 D-fructose 생산 에 있어서, Regy Johnson(Johnson 등, 2009) 등의 연구에 따르 면, 카사바와 고구마에서 추출된 D-glucose로부터 D-fructose 로의 전환율은 37-38\%로 보고되어져 있는데, 본 연구에서 Fungamyl 800L과 glucose isomerase의 순차적 반응에 의해 starch로부터 D-fructose의 생산도 유사한 결과를 나타내었 다. 본 연구의 결과로부터 고농도 starch 기질의 제조 및 고농 도 glucose isomerase 적용 기술의 개발은 향후 amylase와 glucose isomerase의 순차적 반응에 의해 보다 더 효율적인 D-fructose 생산기술로 적용될 수 있을 것으로 기대되어졌다.

\section{효소 동시반응에 의한 starch로부터 D-fructose 생산에 $\mathrm{pH}$ 가 미치는 영향}

본 연구에서는 Fungamyl 800L과 glucose isomerase의 동 시 반응에 의해 starch로부터 D-fructose 생산에 대하여 검토 하였다. 두 효소를 starch와 동시에 반응하기 위해서는 두 효 소의 동시 반응에 요구되는 $\mathrm{pH}$ 와 온도에 대한 조건의 규명이 중요한데, 두 효소의 최적 반응 온도는 $55^{\circ} \mathrm{C}$ 로 동일하였지만 효소 반응 최적 $\mathrm{pH}$ 가 Fungamyl $800 \mathrm{~L}$ 은 $\mathrm{pH}$ 5.0, glucose isomerase는 $\mathrm{pH}$ 7.5로 상이하여, 두 효소의 동시 반응에 요구 되는 $\mathrm{pH}$ 조건을 규명하고자 하였다. 두 효소의 동시반응을 위 해, 기질과 각 효소 농도는 앞에서 진행한 순차적 효소반응에 서 도출된 연구결과를 적용하여 20\% starch, $80 \mathrm{U} / \mathrm{g}$ Fungamyl $800 \mathrm{~L}$, 그리고 $35 \mathrm{U} / \mathrm{mL}$ glucose isomerase을 이용하였으며, 반응 온도는 $55^{\circ} \mathrm{C}$ 로 하여 두 효소의 동시반응에 효과적인 $\mathrm{pH}$ 조건을 검토하였다. 두 효소를 $\mathrm{pH}$ 3.0-9.0 범위의 $\mathrm{pH}$ 환경에 서 starch, Fungamyl 800L, glucose isomerase를 동시에 첨가 하여 효소반응을 진행하면서 starch로부터 생산된 D-glucose 그리고, D-fructose를 분석 검토하였다. Fungamyl 800L과 glucose isomerase의 동시반응에 의해 starch로부터 D-glucose, $\mathrm{D}$-fructose를 검토한 결과, starch로부터 D-glucose의 생산에 있어서 $\mathrm{pH}$ 4.0, 5.0 부근의 산성 영역에서는 Fungamyl 800L 의 가수분해 활성이 우세하여 starch로부터 D-glucose의 최 대 생산의 특성을 보였다(Fig. 8A). 하지만, $\mathrm{pH} 7.0$ 이상의 조건에서는 D-glucose 생산이 약 $50 \%$ 까지 감소하는 결과를 나 타내었다. 그리고, starch로부터 생산된 D-glucose를 D-fructose 로 전환하는 glucose isomerase의 이성화 반응에 있어서 $\mathrm{pH}$ $5.0,6.0$ 조건에서 최대의 D-fructose 생산을 나타내었다(Fig. $8 \mathrm{~B})$. 하지만, glucose isomerase의 최적 $\mathrm{pH}$ 환경인 7.5 부근 의 조건에서는 D-fructose 생산이 약 $70 \%$ 까지 감소하는 결과 를 보였다. 이러한 결과는 Fungamyl 800L과 glucose isomerase 의 동시 반응에 있어서 $\mathrm{pH} 7.0$ 이상의 조건에서는 Fungamyl $800 \mathrm{~L}$ 의 starch 가수분해 활성이 감소하여 D-fructose를 생산하

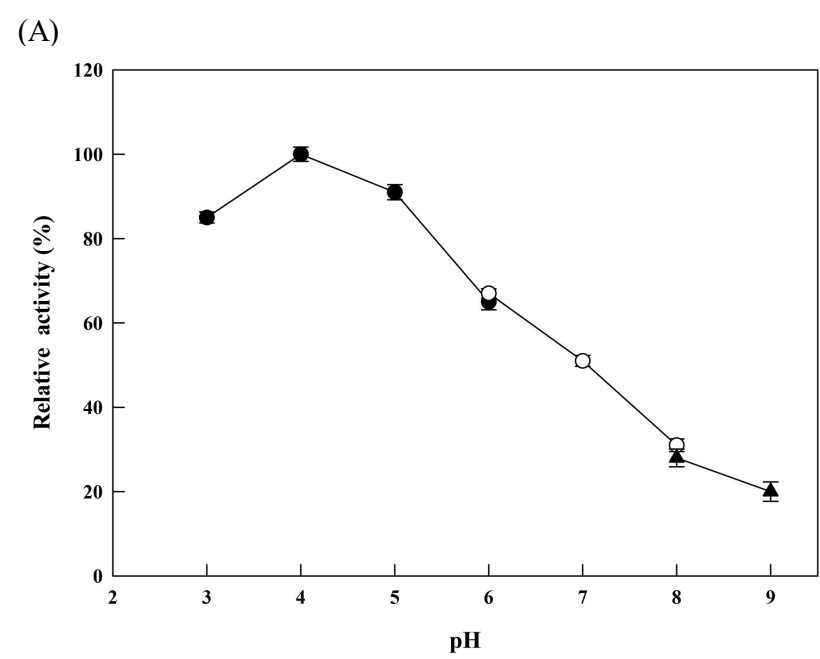

(B)

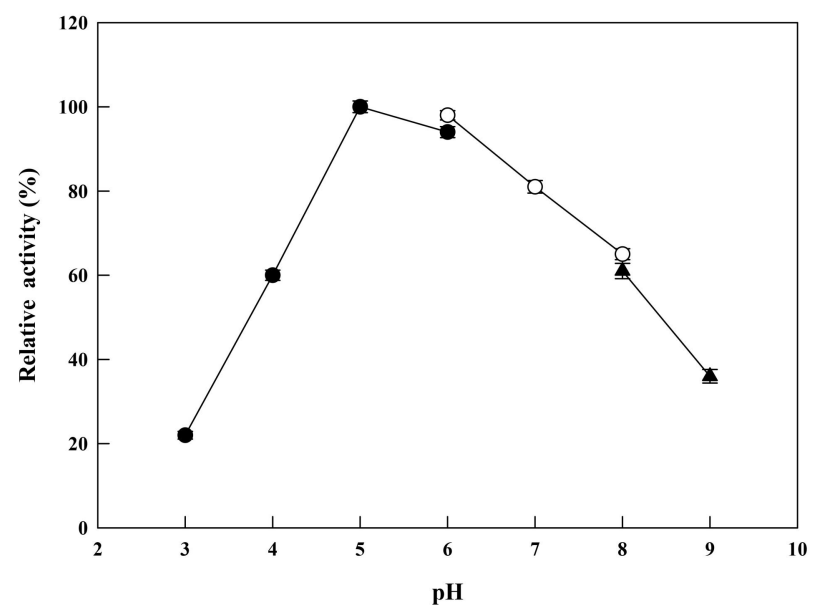

Fig. 8. Effect of $\mathrm{pH}$ on the production of D-glucose (A) and D-fructose (B) by simultaneous enzyme reaction.

The reactions were performed in $50 \mathrm{mM}$ citric acid buffer $(0, \mathrm{pH} 3.0-6.0)$ or $50 \mathrm{mM}$ phosphate buffer $(\mathrm{O}, \mathrm{pH} 6.0-8.0)$ or $50 \mathrm{mM}$ Tris buffer $(\boldsymbol{\Lambda}$, pH 8.0-9.0) containing $20 \%$ of starch, $80 \mathrm{U} / \mathrm{g}$ of Fungamyl $800 \mathrm{~L}$ and $35 \mathrm{U} / \mathrm{mL}$ of glucose isomerase at $55^{\circ} \mathrm{C}$ for $2 \mathrm{~h}$. Data represent the means of three experiments with standard deviation $(\mathrm{p}<0.05)$.

는 기질인 D-glucose 생산이 원활하지 않아 glucose isomerase 의 이성화 반응에도 영향을 미쳤을 것이라고 추측하였다. 이 러한 연구 결과로부터 두 효소의 동시반응에 의해 starch로부 터 D-fructose를 생산하는 반응은 Fungamyl 800L의 가수분 해 활성과 glucose isomerase의 이성화 반응 활성의 감소에 영향을 미치지 않는 $\mathrm{pH} 5.0$ 조건에서 반응을 진행하기로 하 였다.

\section{효소 동시반응에 의한 starch로부터 D-fructose 생산}

Fungamyl $800 \mathrm{~L}$ 과 glucose isomerase의 동시반응에 의해 
starch로부터 D-fructose 생산을 검토하기 위하여 $\mathrm{pH} 5.0$ 의 buffer로 제조된 $20 \%$ starch에 두 효소를 동시에 첨가하여 $55^{\circ} \mathrm{C}$ 에서 반응을 진행하면서 일정시간 간격으로 반응시료를 채취 하여 D-fructose 생산량을 분석하였다. Starch에 Fungamyl $800 \mathrm{~L}$ 를 반응시킨 후 glucose isomerase를 첨가하여 순차적인 효소 반응으로 starch로부터 D-fructose를 생산하는 방법에서 는 반응 2시간 후에 D-fructose 생산이 최대 생산량인 18.7 $\mathrm{g} / \mathrm{L}$ 에 도달하였고, 그 후 반응시간이 증가하여도 D-fructose 생산량의 변화는 확인되지 않았었다(Fig. 7). 하지만, 기질 starch에 두 효소를 동시에 첨가하여 동시반응에 의해 starch 로부터 D-fructose를 생산하는 반응에서는 반응 2시간까지 $12.3 \mathrm{~g} / \mathrm{L}$ 의 D-fructose가 생산되어 순차적 효소반응과 비교 하였을 때 약 $65 \%$ 의 D-fructose 생산성을 나타내었다. 하지 만, 효소의 동시반응의 조건에서는 순차적인 효소반응과는 달리 반응시간이 증가하면 할수록 지속적으로 D-fructose 생 산량이 증가하는 현상을 나타내었다. 반응 2시간 후에도 지 속적으로 D-fructose 생산량이 증가하면서 반응 18시간 이후 부터는 D-fructose 생산이 포화에 도달하면서 최종적으로 반 응 22시간에서 약 $39 \mathrm{~g} / \mathrm{L}$ 의 D-fructose가 생산되었다(Fig. 9). 이러한 결과는 효소의 순차적 반응보다 동시반응을 진행하였 을 때 starch로부터 생산되는 D-fructose의 양은 약 2 배 이상 의 생산이 가능하다는 것을 시사해 주었다. 이러한 결과는 Fungamyl 800L과 glucose isomerase의 순차적 반응에서는 두 효소가 가지고 있는 $\mathrm{pH}$ 의 특성이 상이하여 Fungamyl $800 \mathrm{~L}$ 의 효소반응 후 첨가되는 glucose isomerase의 활성을 위해 조성된 $\mathrm{pH} 7.5$ 조건에서는 Fungamyl $800 \mathrm{~L}$ 의 starch에

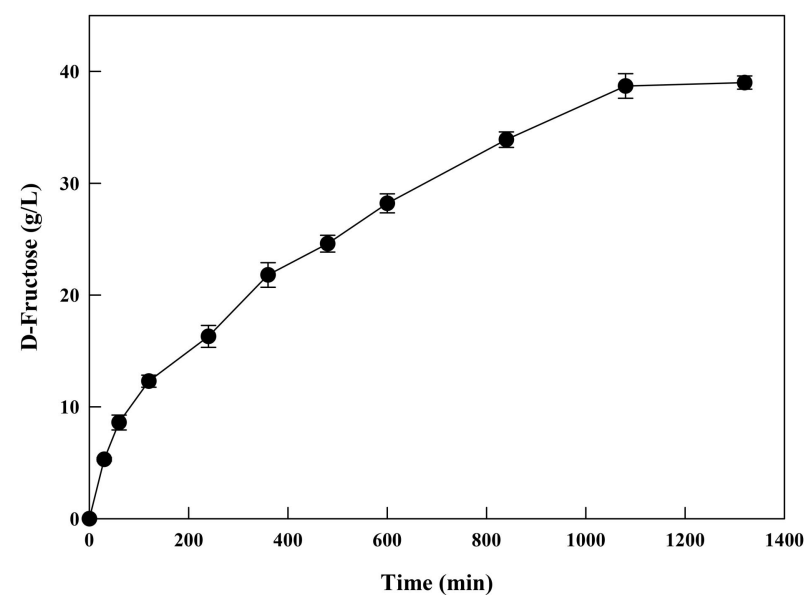

Fig. 9. Production of D-fructose from starch by simultaneous reaction of Fungamyl $800 \mathrm{~L}$ and glucose isomerase.

The reaction was performed simultaneously in $50 \mathrm{mM}$ citric acid buffer (pH 5.0) containing $20 \%$ starch, $80 \mathrm{U} / \mathrm{g}$ of Fungamyl $800 \mathrm{~L}$ and 35 $\mathrm{U} / \mathrm{mL}$ of glucose isomerase at $55^{\circ} \mathrm{C}$. Data represent the means of three experiments with standard deviation $(\mathrm{p}<0.05)$.
대한 가수분해 활성이 원활하지 않아 D-glucose의 공급이 더 이상 이루어지지 않아서 glucose isomerase의 이성화반응이 진행되지 않았을 것이라고 예상되어졌다. 하지만, 두 효소의 동시 반응의 조건에서는 두 효소의 활성에 공통적으로 효과 적인 $\mathrm{pH}$ 조건(pH 5.0)을 규명하여 효소 반응 환경을 조성한 것이 두 효소의 활성이 반응 중에도 지속되는데 효과적으로 영향을 미쳤다고 시사되어졌다. 두 효소의 동시반응에서 조 성된 $\mathrm{pH} 5.0$ 조건에서는 Fungamyl 800L에 의한 starch 가수 분해 활성 및 glucose isomerase에 의한 D-glucose를 D-frucose 로 이성화하는 반응이 보다 더 장시간 지속될 수 있어서 최종 적으로 starch로부터 D-fructose 생산이 반응시간이 증가하면 할수록 지속적으로 향상될 수 있었다고 판단되어졌다. 이러 한 결과로부터 효소 특성이 상이한 2종류 이상의 효소들을 적용하여 다당체로부터 목적 단당류를 생산할 경우 각각의 효소의 최적조건을 적용하여 순차적인 효소 반응을 이용하는 것보다 두 효소의 활성에 효과적인 공통적인 효소반응 조건 을 규명하여 효소들의 동시반응에 의한 목적 단당류 생산이 보다 더 효과적일 수 있다는 결과를 본 연구로부터 도출하였 다. 이러한 효소 적용 기술은 향후 가수분해, 이성화 반응 또 는 에피머반응과 같이 복합효소를 적용하여 다당체로부터 기 능성 단당류를 생산할 수 있는 효소 적용 신기술로서 활용 될 수 있을 것으로 예상되며, 농산부산물의 재활용을 통하여 부가가치를 창출할 수 있는 미래 지향적 효소적용 생물전환 신기술로서도 활용될 수 있을 것으로 기대되어진다.

\section{요 약}

상업용 효소 amylase와 glucose isomerase를 이용하여 starch로부터 D-fructose를 생산하기 위하여, 두 상업용 효소 를 starch와 순차적반응(sequential reaction)과 동시반응 (simultaneous reaction)을 통해 D-fructose 생산을 수행하였 다. Starch로부터 D-fructose를 생산하는 데 있어서 가장 효과 적인 strarch 기질 농도는 $20 \%$, amylase인 Fungamyl $800 \mathrm{~L}$ 의 효소농도는 $80 \mathrm{U} / \mathrm{g}$, 그리고, glucose isomerase의 효소 농도 는 $30 \mathrm{U} / \mathrm{mL}$ 로 규명되었다. 효소의 순차적 반응에 의하여 starch로부터 D-fructose 생산을 위하여, starch와 Fungamyl $800 \mathrm{~L}$ 을 $\mathrm{pH} 5.0,55^{\circ} \mathrm{C}$ 조건에서 2시간 동안 효소 반응을 진행 한 결과, $56 \mathrm{~g} / \mathrm{L}$ 의 D-glucose가 starch로부터 생산되었다. 그 리고, 본 효소 반응액을 $\mathrm{pH}$ 6.0으로 조정한 후 연속해서 glucose isomerase를 첨가하여 2시간동안 효소 반응을 진행 한 결과, 최종적으로 $18.5 \mathrm{~g} / \mathrm{L}$ 의 D-fructose가 생산되었다. 하 지만, 효소순차반응에서는 효소 반응시간이 증가하여도 더 이상의 D-fructose 생산량 증가는 보이지 않았다. Fungamyl 800L과 glucose isomerase의 동시반응을 통하여 starch로부 
터 D-fructose의 생산을 검토하기 위하여, 두 효소의 동시반 응 조건을 검토한 결과, 두 효소의 최적 반응 온도는 $55^{\circ} \mathrm{C}$ 로 동일하였지만, 최적 $\mathrm{pH}$ 가 상이하여 두 효소의 활성 저해를 보 이지 않는 $\mathrm{pH}$ 조건을 검토하였다. 그 결과, $\mathrm{pH}$ 5.0에서는 두 효소의 활성 저해 현상이 나타나지 않아서 $\mathrm{pH} 5.0,55^{\circ} \mathrm{C}$ 조건 에서 starch와 두 효소를 동시에 첨가하여 반응을 진행한 결 과, 효소 반응시간이 증가함에 따라 지속적으로 $\mathrm{D}$-fructose 생산량이 증가하는 현상을 나타내었으며, 반응 18 시간 후에 최대 $39 \mathrm{~g} / \mathrm{L}$ 의 D-fructose가 starch로부터 생산되었다. 이러한 결과로부터 효소반응특성이 상이한 두 효소(Fungamyl 800L, glucose isomerase)를 적용하여 starch로부터 가수분해반응과 이성화 반응을 통해 D-fructose를 생산하는 데 있어서 효소의 순차적인 반응보다는 동시반응이 보다 더 효과적인 D-fructose 생산 방법이라는 것이 시사되었다.

\section{감사의 글}

본 논문은 2019년도 대구가톨릭대학교 교내연구비 지원에 의한 것으로 감사드립니다.

\section{Conflict of interests}

The authors declare no potential conflict of interest.

\section{ORCID}

Chang-Su Park https://orcid.org/0000-0002-0770-5068

\section{References}

Amaral-Fonseca M, Roberto MS, Roberto FL, Paulo WT. Optimization of simultaneous saccharification and isomerization of dextrin to high fructose syrup using a mixture of immobilized amyloglucosidase and glucose isomerase. Catal, 362, 175-183 (2021)

Bhosale SH, Rao MB, Deshpande VV. Molecular and industrial aspects of glucose isomerase. Microbiol Rev, 60, 280-300 (1996)

Hanover LM, White JS. Manufacturing, composition, and applications of fructose. Am J Clin Nutr, 58, 724-732 (1993)

Johnson R, Padmaja G, Moorthy SN. Comparative production of glucose and high fructose syrup from cassava and sweet potato roots by direct conversion techniques.
Innov Food Sci Emerg Technol, 10, 616-620 (2009)

Kaneko T, Takahashi S, Saito K. Characterization of acidstable glucose isomerase from Streptomyces sp., and development of single-step processes for high-fructose corn sweetener (HFCS) production. Biosci Biotechnol Biochem, 64, 940-947 (2000)

Karaoglu H, Yanmis D, Sal FA, Celik A, Canakci S, Belduz AO. Biochemical characterization of a novel glucose isomerase from Anoxybacillus gonensis $\mathrm{G} 2^{\mathrm{T}}$ that displays a high level of activity and thermal stability. J Mol Catal B Enzyme, 97, 215-224 (2013)

Kohli I, Joshi NC, Varma A. Production, purification and applications of raw starch degrading and calciumindependent $\alpha$-amylase from soil rich in extremophile. Int J Biol Macromol, 162, 873-881 (2020)

Lama L, Nicolaus B, Calandrelli V, Romano I, Basile R, Gambacorta A. Purification and characterization of thermostable xylose(glucose) isomerase from Bacillus thermoantarcticus. J Ind Microbiol Biotechnol, 27, 234-240 (2001)

Lee C, Saha BC, Zeikus JG. Characterization of Thermoanaerobacter glucose isomerase in relation to saccharidase synthesis and development of single-step processes for sweetener production. Appl Environ Microbiol, 56, 2895-2901 (1990)

Lee CY, Zeikus JG. Purification and characterization of thermostable glucose isomerase from Clostridium thermosulfurogenes and Thermoanaerobacter strain B6A. Biochem J, 273, 565-571 (1991)

Lee SK, Mun SH, Shin MS. Enzyme-resistant starch formation from mild acid-treated maize starches. J Food Sci, 29, 1309-1315 (1997)

Luz DA, Rodrigues AKO, Silva FRC, Torres AE, CavalcanteJr CL, Brito ES, Azevedo DCS. Adsorptive separation of fructose and glucose from an agroindustrial waste of cashew industry. Bioresour Technol, 99, 24552465 (2008)

Miller GL. Use of dinitrosalicylic acid reagent for determination of reducing sugar. Anal Chem, 31, 426-428 (1959)

Miyafuji H, Nakata T, Ehara K, Saka S. Fermentability of water-soluble portion to ethanol obtained by supercritical water treatment of lignocellulosics. Appl Biochem Biotechnol, 124, 963-971 (2005)

Mukesh Kumar DJ, Silambarasan T, Renuga R, Ravi Kumar 
M, Karthigai Devi S, Ramamurthy D, Kalaichelvana PT. Production, optimization and characterization of $\alpha$-amylase and glucose isomerase producing Bacillus megaterium BPTK5 from cassava waste. Eur J Exp Biol, 2, 590-595 (2012)

Nakata T, Miyafuji H, Saka S. Bioethanol from cellulose with supercritical water treatment followed by enzymatic hydrolysis. Appl Biochem Biotechnol, 130, 476-485 (2006)

Reshmi R, Sanjay G, Sugunan S. Enhanced activity and stability of a-amylase immobilized on alumina. Catal Commun, 7, 460-465 (2006)

Parker K, Sala M, Nwosu VC. High fructose corn syrup: Production, uses and public health concerns. Biotechnol Mol Biol Rev, 5, 71-78 (2010)

Priest FG. Extracellular enzyme synthesis in the Bacillus genus. Bacteriol Rev, 41, 711-753 (1977)

Shofiyah SS, Yuliani D, Widya N, Sarian FD, Puspasari F, Radijasa OK, Ihsanawati, Natalia D. Isolation, expression, and characterization of raw starch degrading $\alpha$-amylase from a marine lake Bacillus megaterium NL3. Heliyon, 6, e05796 (2020)
Takeshita K, Suga A, Takada G, Izumori K. Mass production of $\mathrm{d}$-psicose from $\mathrm{d}$-fructose by a continuous bioreactor system using immobilized D-tagatose 3epimerase. J Biosci Bioeng, 90, 453-455 (2000)

Tsumura N, Sato T. Enzymatic conversion of D-glucose to D-fructose. Part II. Properties of the enzyme from Streptomyces phaeochromogenes. Agr Biol Chem, 29, 1129-1134 (1965)

Van der Maarel MJEC, Van der Veen B, Uitdehaag JCM, Leemhuis H, Dijkhuizen L. Properties and applications of starch-converting enzymes of the $\alpha$-amylase family. $\mathrm{J}$ Biotechnol, 94, 137-155 (2002)

Xu J, Sagnelli D, Faisal M, Perzon A, Taresco V, Mais M, Perzon A, Hebelstrup KH, Ulvskov P, Jorgensen B, Chen L, Howdle SM, Blennow A. Amylose/cellulose nanofiber composites for all-natural, fully biodegradable and flexible bioplastics. Carbohydr Polym, 253117277 (2021)

Zhu Z, Li C, Liu X, Gao D, Wang X, Ranokura M, Qin HM, Lu F. Biochemical characterization and biocatalytic application of a novel D-tagatose 3-epimerase from Sinorhizobium sp.. RSC Adv, 9, $2919-2927$ (2019) 